\title{
EFFECTS OF PLANT EXTRACTS AS PRE-MILKING DAIRY COW TEAT SANITIZER
}

\author{
S. Mureza*1, C. J. Smit ${ }^{1}$, M. C. Muya ${ }^{2}$ and F. V. Nherera-Chokuda ${ }^{3}$ \\ ${ }^{1}$ University of South Africa, P. O Box 39, Florida 0003; ${ }^{2}$ ARC-Animal Production Institute, P/BagX2, Irene, 0062. \\ ${ }^{3}$ National Emerging Red Meat Producers Organization (NERPO), 160 Garsfontein Road, Pretoria, 0081; South Africa. \\ Corresponding author's email: fsd@nerpo.org.za
}

\begin{abstract}
The aim of the study was to assess effects of cactus (Opuntia ficus-indica) and garlic (Allium sativum) extracts on cow teat sanitization and raw milk pathogenic bacteria. Cactus and garlic extracts have antimicrobial properties that are sourced from their micronutrients and secondary metabolites. Antimicrobial strength of cactus (Tormentosa, Meyers, and Corfu), and garlic extracts were compared against a pre-milking commercial teat dip (Biocell).A double Latin square design with six mid-lactating Holstein cows was used. The study found that cactus and garlic extracts inhibit Staphylococcus aureus (S. aureus) and Escherichia coli (E. coli).Moreover, Tormentosa and garlic extracts were most effective bacteria inhibitors at $1.56 \mathrm{mg} / \mathrm{mL}$ and $3.125 \mathrm{mg} / \mathrm{mL}$ respectively. As a result, commercial dip and Tormentosa and garlic extracts were tested as pre-milking teat sanitizers during summer and autumn. Summer results showed bacteria reduction ranging from $55-58 \%$ for garlic, $29-43 \%$ for Tormentosa and $33-59 \%$ for Biocell. Autumn bacteria count varied widely. Milk bacteria count also declined. Overall, garlic was the most effective in reducing milk and teat bacteria, while cactus was effective over time. Biocell results varied and this provides for consideration to utilize cactus and garlic extracts as pre-milking teat dip to combat pathogenic bacteria.
\end{abstract}

Key words: Allium sativum; antibacterial activity; cactus; food safety; mastitis; milk pathogens. https://doi.org/10.36899/JAPS.2021.2.0228

Published online October 03,2020

\section{INTRODUCTION}

Diverse species of herbaceous and succulent herbs including aloes, cactus, and garlic are adapted to South African biomes and function as supplement and pharmaceutical ingredients in livestock production systems (Chauhan, 2006). Herbs are source of antioxidants with antimicrobial properties. Flavonoids and phenols from herbs interfere with bacterial cell protein synthesis by destroying the pathogen peptidoglycan cell wall which results in leakage of cellular contents. The peptidoglycan layer is essential for bacteria survival hence membrane damage kills the bacteria. Bacterial contamination of animal-sourced foods causes a serious threat to both animal and human health. Milk is prone to contamination as teats are exposed to environmental microbes. Pre-milking teat disinfection decrease teat surface bacteria, milk contamination and intramammary infection with mastitis pathogens (National Mastitis Council, 2013).Common strategies for reducing pathogen load include hand washing of teats with water and drying with paper towels (Vissers et al., 2007).

Main ingredients in sanitizers are chlorine, dodecyl benzene sulfonic acid and alcohol which act by infiltrating bacterial cell membranes, leading to bacterial inhibition or death. The teat skin epidermis has a thick layer of keratin and has no sweat glands and therefore is prone to drying and cracking. Extracts from plants contain compounds that moisturize the teat skin. The greatest challenge in clean milk production is pathogen resistance to antimicrobials. The wide diversity of secondary component in herbal extracts reduces the risk of antimicrobial resistance relative to synthetic sanitizers which are composed of single or few active ingredients. Some of the active ingredients in synthetic sanitizers irritate skin and cause thickness (Rasmussen, 2003).The aim of the study was to assess the effects of garlic and cactus extracts on cow teat sanitization.

\section{MATERIALS AND METHODS}

The research was conducted at the Animal Production Institute of the Agricultural Research Council (ARC) at Irene in Pretoria, South Africa. Three varieties of the spineless Cactaceae of Opuntia ficus-indica (Tormentosa, Meyers, and Corfu) and garlic (Allium sativum) cloves and a commercial teat dip (Biocell an iodine based teat dip) were selected for the experiment based on levels of secondary compounds. Ethics for the research was approved (UNISA CAES Animal Research Review Committee, Ref: 2016/CAES/085).

Phenolic composition and antibacterial assays: Leaves of Cactaceae (Tormentosa, Meyers, and Corfu), 5 - 10 $\mathrm{cm}$ were harvested in summer (November) and autumn (April). The leaves were sliced and dried in a conventional oven at $45^{\circ} \mathrm{C}$ and milled through a $1 \mathrm{~mm}$ sieve. The powder $(10 \mathrm{~g})$ from each plant was dissolved in $150 \mathrm{~mL}$ of distilled water, sonicated for 20 minutes 
(Brandon, model 8510E-MTH, Danbury, USA) and filtered using Whatman (41) filter paper. The supernatant was placed in a deep freezer for 3 hours at $-30{ }^{\circ} \mathrm{C}$ and freeze dried for 3 days pending chemical analysis. The freeze-dried samples were stored in amber bottles at $4{ }^{\circ} \mathrm{C}$ prior to use. Garlic cloves were harvested in both seasons, crushed and mixed with water at $1 \mathrm{~g}$ : $15 \mathrm{mLand}$ was analyzed for secondary metabolites. Qualitative analysis for secondary metabolites in garlic and cactus extracts was done (Harborne, 1973). Total phenols in water extracts were determined using Folin- Ciocalteu reagent and external calibration with garlic acid (Singelton et al., 1999), and total flavonoids were measured (Dewanto et al., 2002). Antibacterial assay of $S$. aureus and E. coli clinical strains was performed using the broth micro dilution method to determine minimum inhibitory concentration (MIC) and minimum bactericidal concentration (MBC) (Eloff, 1998). Garlic and Tormentosa were selected for teat sanitizing experiment.

Teat sanitization and milk tests: Six mid lactating multiparous Holstein-Friesian cows with milk SCC $\leq 250$ x $10^{3} / \mathrm{mL}$ for 30 days (from 60 to 90 days in milk) were housed in individual pens that had partial roof cover and partial concrete flooring $\left(30 \mathrm{~m}^{2}\right)$. A double Latin square with 3 periods and 3 treatments was applied. Crushed garlic and extract of Tormentosa were selected based on MIC and tested against a commercial teat dip (Biocell). The cows were fed a balanced total mix ration with adlib hay and water. Pre-teat dipping and milk sampling were done in both summer and autumn. Average temperatures were $34{ }^{\circ} \mathrm{C}$ in summer and $29^{\circ} \mathrm{C}$ in autumn. Milking was done using an automatic machine twice daily at $06: 00 \mathrm{~h}$ and 15:00h.Pre-teat dipping was done at each milking period (am and pm) and post dipping was standardized with an iodine-based product.

Microfiber cloths were soaked in sterile container with $100 \mathrm{~mL}$ of fresh extract 10 minutes before application and the extract concentration was 1g: $15 \mathrm{~mL}$.Commercial wipes (Biocell) were used as a control for pre-teat disinfecting against garlic and cactus extracts. Teats were cleaned with the microfiber cloth and commercial wipes for 20 seconds and the cloth disposed immediately. Swabbing of teats was done using sterile cotton swabs moistened in buffered peptone water before and after pre-teat dipping. Two swabs were collected on a single teat per cow and were stored in ice and analyzed for total bacteria counts according to standards of the National Mastitis Council (Harmon et al., 1990), within 24 hours. Milk samples were collected before and after application of pre-teat sanitizer. The teat was stripped on a mastitis cup and the milk discarded. A fresh stream of $100 \mathrm{~mL}$ was collected into sterile bottles with no preservative and immediately chilled at $-4{ }^{\circ} \mathrm{C}$ for standard plate count. A second sample was collected from each cow after pre-teat sanitization and the cows were milked.
All teats were post dipped in F10, an iodine dip after milking. The first $3 \mathrm{~d}$ collected data following changeover of treatment was not analyzed to avoid residual effect of the previous treatment, and data from day 4 to 9 of each period was analyzed.

Environmental pathogen assessment: Top soil samples (10 cm deep) were randomly collected from three spots in each cow pen. Feed samples were collected at each feeding time and sealed in plastic bags. Fecal samples were hand collected once weekly in the crush pen from each cow's rectum using gloves and samples were chilled at $4{ }^{\circ} \mathrm{C}$. Water was collected from the drinking troughs into sterile containers once per period. No preservative was used and all samples were analyzed within $24 \mathrm{~h}$ for presence of E coli, S. aureus and Streptococcus spp. using blood agar (Cowan et al., 1993) and MacConkey agar. Serially diluted samples were inoculated into blood plate agar petri plates and incubated at $37{ }^{\circ} \mathrm{C}$ for $24 \mathrm{~h}$. Bacteria was identified by colony morphology and gram staining.

Statistical analyses: Data on inhibitory activity of extract were analyzed using one-way analysis of variance (ANOVA) for a complete randomized design using SAS (2017). Difference was considered significant at $P<0.05$. Data on total bacteria in components (udder surfaces, milk) was assessed for normality and equal variance and transformed to $\log _{10}$. Data was analyzed for a Latin square design to determine effects of treatment, season and interactions. Turkey's test was performed to determine mean differences at $P<0.05$.

\section{RESULTS}

Environmental bacteria analysis: Table 1 shows bacterial counts in feeds, soil and water. S. aureus was low ( $<10$ coliforms units) in feeds, soil, and feces in both seasons but not detected in water. E. coli were low in feeds, but levels were higher in soil and feces.

Phytochemical screening of cactus extracts and crushed garlic: Alkaloids, glycosides, terpenoids, flavonoids, and tannins were showed in cactus and garlic extracts (Table 2.1). Garlic had low levels of both flavonoids and phenolics relative to cactus (Table 2.2). Corfu was high in secondary compounds and differed from Tormentosa, Meyers, and garlic.

Minimal inhibitory concentration (MIC) and Minimal bactericidal concentration (MBC): Low concentrations of Tormentosa inhibited E. coli growth (MIC $=1.56$ $\mathrm{mg} / \mathrm{mL}$ ) compared to Meyers and Corfu at 6.25 and 12.5 $\mathrm{mg} / \mathrm{mL}$, respectively (Table 3 ). Minimum bactericidal concentration against $E$. coli and $S$. aureus for Tormentosa was 12.5 and $6.25 \mathrm{mg} / \mathrm{mL}$ similar to Corfu and Meyers. Garlic and commercial dip had MIC and MBC of $3.125 \mathrm{mg} / \mathrm{mL}$ against $E$. coli and $S$. aureus. 
Table 1. Total bacteria counts (cfu/ mL) in soil, water, feces, feed (summer and autumn).

\begin{tabular}{lccc|ccc}
\hline & \multicolumn{2}{c}{ Escherichia coli } & P & \multicolumn{2}{c}{ Staphylococcus aureus } & P \\
\hline & Summer & Autumn & & Summer & Autumn & $*$ \\
Feces & $5163333^{\mathrm{a}}$ & $182000^{\mathrm{b}}$ & $* *$ & $<10$ & 0 & $\mathrm{~N}$ \\
Water & $0^{\mathrm{b}}$ & $220^{\mathrm{a}}$ & $* *$ & 0 & $<10$ & $\mathrm{~N}$ \\
Feed & $0^{\mathrm{b}}$ & $10^{\mathrm{a}}$ & $* *$ & $<210$ & $<10$ & $\mathrm{Ns}$ \\
Soil & $663^{\mathrm{a}}$ & $593^{\mathrm{b}}$ & $* *$ & $<9$ & 2 \\
\hline
\end{tabular}

LS means within a row with different superscripts vary; ** $P<0.05$; ns not significant

Effects of pre-teat dipping on teat bacteria counts: Teats bacterial counts before dipping were high in both seasons but decreased after teat dipping. There was a consistent reduction following sanitization with garlic $(55$ - 58\%) but wide variation with commercial (33 - 59\%) and cactus $(29-43 \%)$ in summer (Table 4). Teat sanitization in autumn also reduced bacterial load but less effectiveness on all products (garlic 17 - 60\%, cactus 11 $66 \%$ and commercial dip (16 - 57\%; Table 5). Seasonal and extract interactions were noted. Day treatment interaction was not significant. Garlic was more effective in summer than autumn while commercial sanitizer and Tormentosa were more effective in autumn.
Milk bacteria: Pre-milking teat dipping was associated with low bacterial counts in milk in both seasons (Figure 1 and Figure 2). Mean total bacteria counts (TBC) in milk before teat sanitization ranged between 50 and $60 \mathrm{cfu} / \mathrm{mL}$ and the levels declined after dipping. Change in total bacterial counts was evident from day three reaching to levels of $80-90 \%$ reduction in milk TB after 5 days. There were differences between garlic and cactus in summer during the first four days of sampling and none thereafter. Difference between garlic and commercial were not significant. By day nine, all applications had similar effect on TBC.

Table 2.1 Composition of secondary compounds in summer and autumn.

\begin{tabular}{lcccccc}
\hline & Flavonoids & Saponins & Glycosides & Terpenoids & Tannins & Alkaloids \\
\hline Meyers & + & - & + & + & + & + \\
Tormentosa & + & - & + & + & + & + \\
Corfu & + & - & + & - & + & + \\
Garlic & + & + & + & - & + \\
\hline
\end{tabular}

$+:$ presence of constituent; -: absence of constituent

Table 2.2. Total phenolics and flavonoids contents in plant extracts.

\begin{tabular}{lccc}
\hline Source & & Flavonoids $(\mathrm{mg}$ CE/g) & Phenols $(\mathrm{mg}$ GAE/g) \\
\hline Cactus & Variety & LS mean + Standard deviation & $13.9^{\mathrm{a}} \pm 0.42$ \\
& Corfu & $1.1^{\mathrm{a}} \pm 0.07$ & $10.4^{\mathrm{b}} \pm 0.18$ \\
& Tormentosa & $0.9^{\mathrm{bc}} \pm 0.05$ & $7.9^{\mathrm{c}} \pm 0.01$ \\
Garlic & Meyers & $1.0^{\mathrm{b}} \pm 0.02$ & $0.8^{\mathrm{d}} \pm 0.10$ \\
P & & $0.7^{\mathrm{c}} \pm 0.05$ & $* *$ \\
\hline
\end{tabular}

LS means with different superscripts within a column vary; ${ }^{*} P<0.05 ; * * P<0.01$

Table 3. MIC (mg/ mL) and MBC performance of different plant extracts against pathogens.

\begin{tabular}{lcccc}
\hline Plant extracts & \multicolumn{1}{c}{$\boldsymbol{E}$. coli } & & S. aureus \\
\hline & MIC & MBC & MIC & MBC \\
Corfu & 12.5 & 12.5 & 6.25 & 6.25 \\
Tormentosa & 1.56 & 12.5 & 6.25 & 6.25 \\
Meyers & 6.25 & 12.5 & 6.25 & 6.25 \\
Garlic & 3.125 & 3.125 & 3.125 & 3.125 \\
Commercial (control) & 3.125 & 3.125 & 3.125 & 3.125 \\
\hline
\end{tabular}

$\mathrm{MIC}=$ minimum inhibitory concentration, $\mathrm{MBC}=$ minimum bactericidal concentration 
Table 4. Summer total bacterial count $\left(\log _{10}:(T B C: c f u / m L)\right.$ on lactating dairy cow teats.

\begin{tabular}{|c|c|c|c|c|c|c|}
\hline Summer & Day4 & Day5 & Day6 & Day7 & Day8 & Day9 \\
\hline \multicolumn{7}{|c|}{ LS mean \pm standard deviation } \\
\hline & $4.13^{\mathrm{a}} \pm 0.01$ & $3.79^{\mathrm{a}} \pm 0.51$ & $4.14^{\mathrm{a}} \pm 0.04$ & $4.12^{\mathrm{a}} \pm 0.06$ & $4.15^{\mathrm{a}} \pm 0.07$ & $3.92^{\mathrm{a}} \pm 0.42$ \\
\hline & Post-dipping count & & & & & \\
\hline Garlic & $1.81^{\mathrm{c}} \pm 0.02$ & $1.72^{\mathrm{b}} \pm 0.03$ & $1.78^{\mathrm{c}} \pm 0.03$ & $1.72^{\mathrm{c}} \pm 0.07$ & $1.76^{c} \pm 0.16$ & $1.74^{\mathrm{b}} \pm 0.16$ \\
\hline Tormentosa & $2.34^{\mathrm{b}} \pm 0.01$ & $2.69^{\mathrm{ab}} \pm 0.20$ & $2.77^{b} \pm 0.02$ & $2.74^{\mathrm{b}} \pm 0.04$ & $2.65^{\mathrm{b}} \pm 0.05$ & $2.61^{\mathrm{b}} \pm 0.02$ \\
\hline Commercial & $1.70^{\mathrm{d}} \pm 0.04$ & $2.38^{\mathrm{ab}} \pm 0.43$ & $2.75^{\mathrm{b}} \pm 0.04$ & $2.61^{\mathrm{b}} \pm 0.02$ & $2.65^{\mathrm{b}} \pm 0.01$ & $2.61^{\mathrm{b}} \pm 0.21$ \\
\hline
\end{tabular}

Means with same superscript within a column are not different: $P<0.05$

Table 5. Autumn total bacteria count $\left(\log _{10}:(\mathrm{TBC} \mathrm{cfu} / \mathrm{mL})\right.$ on lactating dairy cow teats.

\begin{tabular}{|c|c|c|c|c|c|c|}
\hline Autumn & Day4 & Day5 & Day6 & Day7 & Day8 & Day9 \\
\hline \multicolumn{7}{|c|}{$\begin{array}{c}\text { LS mean } \pm \text { standard deviation } \\
\text { Pre-dipping count }\end{array}$} \\
\hline & $4.19^{\mathrm{a}} \pm 0.21$ & $3.81^{\mathrm{a}} \pm 0.11$ & $4.27^{\mathrm{a}} \pm 0.10$ & $2.80^{\mathrm{a}} \pm 0.25$ & $2.75^{\mathrm{a}} \pm 0.16$ & $3.19^{\mathrm{a}} \pm 0.39$ \\
\hline \multicolumn{7}{|c|}{ Post-dipping count } \\
\hline Garlic & $1.69^{c} \pm 0.28$ & $2.72^{\mathrm{ab}} \pm 0.47$ & $2.89^{\mathrm{d}} \pm 0.02$ & $2.33^{\mathrm{a}} \pm 0.11$ & $1.71^{\mathrm{b}} \pm 0.03$ & $1.92^{\mathrm{ab}} \pm 0.43$ \\
\hline Tormentosa & $2.98^{\mathrm{b}} \pm 0.01$ & $3.07^{\mathrm{ab}} \pm 0.32$ & $3.79^{b} \pm 0.06$ & $2.43^{\mathrm{a}} \pm 0.79$ & $1.21^{\mathrm{b}} \pm 0.19$ & $1.10^{\mathrm{b}} \pm 0.45$ \\
\hline Commercial & $1.79^{c} \pm 0.01$ & $2.16^{\mathrm{b}} \pm 0.22$ & $3.45^{\mathrm{c}} \pm 0.01$ & $1.60^{\mathrm{a}} \pm 0.79$ & $2.32 \pm^{\mathrm{a}} 0.02$ & $2.12^{\mathrm{ab}} \pm 0.14$ \\
\hline
\end{tabular}

Means with same superscript within a column are not different. $P<0.05$

Table 6. Effects of seasonal variations and treatment on teat bacterial counts $\left(\operatorname{Lsmean}-\log _{10}\right)$.

\begin{tabular}{lc|ccc}
\hline & Pre-dip levels & Garlic & Tormentosa & Commercial \\
& \multicolumn{4}{c}{ LS mean \pm standard deviation } \\
\hline Summer & $4.04^{\mathrm{a}} \pm 0.25$ & $1.76^{\mathrm{b}} \pm 0.08$ & $2.63 \pm 0.16$ & $2.45 \pm 0.40$ \\
Autumn & $3.50^{\mathrm{b}} \pm 0.67$ & $2.21^{\mathrm{a}} \pm 0.54$ & $2.43 \pm 1.07$ & $2.24 \pm 0.67$ \\
P & 0.016 & 0.008 & 0.527 & 0.356 \\
\hline
\end{tabular}

LS mean values with different superscript within a column differ at $P<0.05$

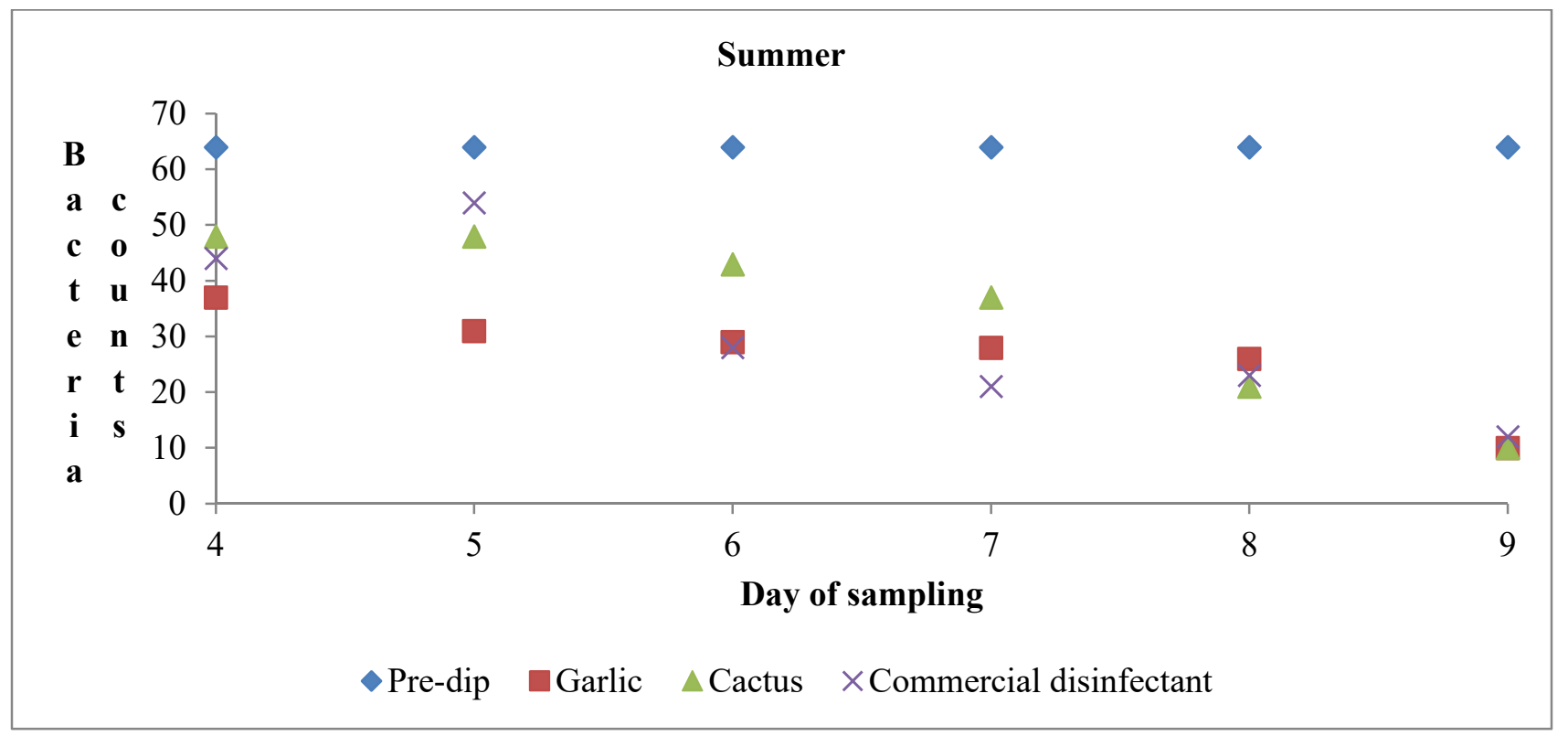

Fig. 1. Summer milk total bacterial counts (milk TBC cfu/mL). 


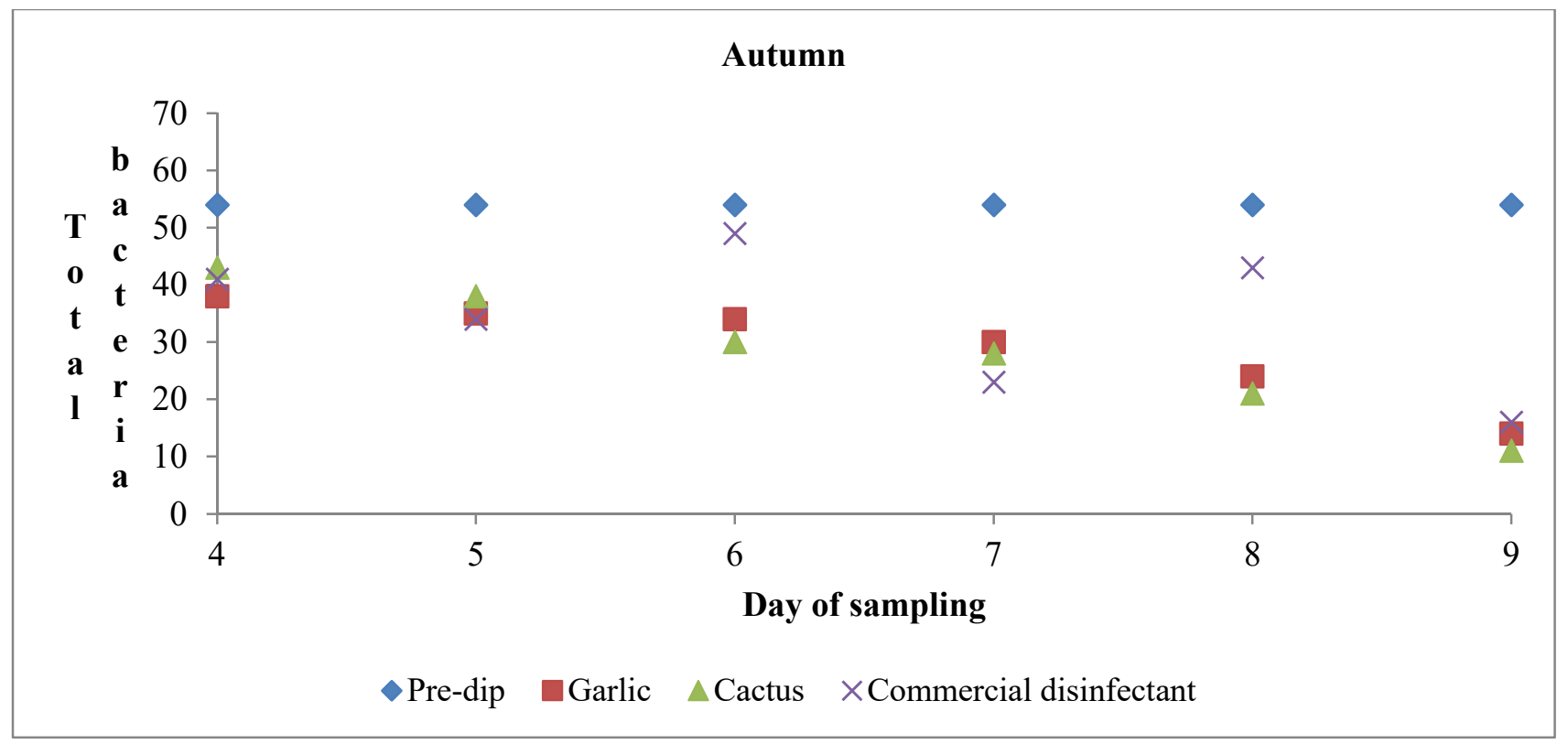

Fig. 2. Autumn milk total bacterial counts (milk TBC cfu/mL).

\section{DISCUSSION}

Pre-teat dipping is a rapid process aimed at instant sanitization to reduce microbial contamination of milk and teat skin. This study revealed the effectiveness of teat dipping using garlic and cactus extracts. Växa Sverige (2015) also reported reduction in intramammary infection with major mastitis pathogens. Secondary metabolites in garlic and cactus extract inhibited bacteria and bacterial contamination of milk. Cactus extracts contained glycosides, terpenoids, flavonoids, alkaloids, and tannins (Dib et al., 2013), while garlic had flavonoids, saponins, tannins, and glycosides. Daglia (2012) noted that plant phenols cause physiochemical and structural damage to bacteria, which is in agreement with this study results as phenols were present in the extracts, and although they were low in garlic they had stronger inhibitory effects as shown by the low MIC and MBC.

Both gram negative and positive bacteria were susceptible to plant extracts, contrary to Abd et al. (2012) who reported negative effects only on gram negative bacteria. Gram-negative bacteria such as E. coli have thin peptidoglycan layers and proteins while gram-positives $S$. aureus have thicker layers and no proteins (Hogan, 2010). Sapkota et al. (2012) confirmed effectiveness of garlic against a wider range of microbes and Daka (2011) confirmed antimicrobial activity of garlic against $S$. aureus and E. coli similar to this study results. Hayek and Ibrahim (2012) documented inhibitory effect of cactus extract on microbial growth of E. coli, in agreement to this study results.

Samples of feeds and water were in low bacterial load; however, E. coli in fresh fecal were high which was inconsistent to levels observed in consumed feeds. Atnafie et al. (2017) also noted high E. coli counts in feces, which is an indicator of poor hygiene and human contamination of the production environment. In this study, levels of $S$. aureus were very low in soils, feces, feeds and water in both seasons, which could be related to low prevalence in the environment and hence low risk of transmission of mastitis.

Garlic and cactus were effective in reducing TB counts in both seasons although the range varied widely. Seasonal variation effectiveness of extracts could be due to variations in bacteria prevalence, which responds to temperature and moisture changes. The MIC and MBC levels were maintained but concentrations of potent phenols could have contributed to the differences, as micro concentrations of anti-oxidants can be biocidal. Garlic was more effective than other extracts possibly due to the potency of phenols and flavonoids in the extract. Commercial sanitizers contain active ingredients at minimum inhibitory levels to optimize costs; additionally, inaccurate dilutions and atmospheric temperatures may render them less effective. Crude plant extracts tend to contain high levels of active ingredients and therefore less likely to be affected by micro-changes. Therefore, utilization of garlic and cactus extracts mitigate contamination challenges and can be used for safe milk production. Communal area farmers that face great challenges with access to resources for clean milk production could use the plant extracts to achieve regulated TB levels for raw milk. The study therefore provides new knowledge that expands application of plant extracts for safe milk production.

Conclusion: Plant extracts from garlic and cactus have revealed a variety of secondary metabolites proven to be beneficial for both human, animal health and hygiene. 
The metabolites include among others flavonoids, saponins, tannins and phenols and are said to be great inhibitors of various bacteria. Antimicrobial activity results for garlic and cactus have proven their effectiveness in inhibiting bacteria growth and multiplication at various concentrations. Teats and milk bacteria loads were also reduced after using the extracts as pre-teat sanitizers, without side effects to the cows. These findings fulfilled the study aims and objectives in a positive way brightening the future use of plant extracts in improving hygiene in dairy production. Pre-teat dipping is crucial, as revealed by the results through reduction of bacteria counts on teats and reduced milk contamination. Garlic and cactus extracts have shown potential as disinfectants. Therefore, they could be harnessed as alternatives to synthetic disinfectants in pharmaceutical and health formulations to combat pathogenic bacteria.

Acknowledgements: We are grateful to the University of South Africa for funding and support as well as Agricultural Research Council for use of their research facilities.

\section{REFERENCES}

Abd Razik, B. M., H. A. Hasan and M. K.Murtadha (2012). The Study of Antibacterial Activity of Plantago Major and Ceratonia Siliqua. The Iraqi Postgraduate, 11(1): 130-135.

Atnafie, B., D. Paulos, M. Abera, G. Tefera, D. Hailu, S. Kasaye, K. Amenu (2017). Occurrence of Escherichia coli $\mathrm{O} 157: \mathrm{H} 7$ in cattle feces and contamination of carcass and various contact surfaces in abattoir and butcher shops of Hawassa, Ethiopia. BMC Microbiol, 17, 24. https://doi.org/10.1186/s12866-017-0938-1.

Chauhan, N. B. (2006). Effect of aged garlic extract on APP processing and tau phosphorylation in Alzheimer's transgenic model Tg2576. J. Ethnopharmacol, 108(3): 385-394.

Cowan, S. J., K. J. Steel, G. I. Barrow,R. K. A. Feltham (1993).Cowan and Steel's Manual for the Identification of Medical Bacteria, 3rd Ed. Cambridge: Cambridge University Press.

Daglia, M. (2012). Polyphenols as antimicrobial agents. Current Opinion in Biotechnology, 23: 174-181.

Daka, D. (2011). Antibacterial effect of garlic (Allium sativum) on Staphylococcus aureus: an in vitro study. In African J. Biotech, 10, 2011, p. 666669.

Dewanto, X., K. Wu, K. Adom, R. U. Liu (2002). Thermal processing enhances the nutritional value of tomatoes by increasing total antioxidant activity. J. Food Chem, 50: 3010-3014.
DIB, H., C. Beghdad, M. Belardi (2013).Phytochemical study of Algerian Opuntia ficus-indica Scholars Research Library Annals of Biological Research, 4 (2): 185-189.

Eloff, J. N. (1998). The presence of antimicrobial compounds in Anthocleistagrandiflora (Loganiaceae) S. Afr. J. Bot, 64: 209-212.

Harborne, J. B. (1973). Phytochemical Methods. Chapman and Hall Limited, London, UK. 49188.

Harmon, R. J., R. J. Eberhart, D. E. Jasper, B. E. Langlois, R. A. Wilson (1990). Microbiological Procedures for the Diagnosis of Bovine Udder Infection.3rd edition, National Mastitis Council Inc., Arlington, VA Page 3.

Hayek, S. A., S. A. Ibrahim (2012). Antimicrobial Activity of Xoconostle Pears (Opuntia matudae) against Escherichia coli O157:H7 in Laboratory Medium. Int. J. Microbiol.

Hogan, M. C. (2010). Bacteria. Encyclopaedia of Earth. Ed's.SidneyDraggan and Cleveland C J, National Council for Science and the Environment, Washington DC.

National Mastitis Council (2013). Proceedings of 52nd Annual Meeting, San Diego, CA,USA, pp 225 239 Oliver SP, Lewis MJ, Ingle TL, Gillespie BE, Matthews KR (1993) Prevention of bovine mastitis by a teat disinfectant containing chlorous acid and chlorine dioxide. J. Dairy Sci, 76: 287-292.

Rasmussen, M. D. (2003). Short term effect of transition from conventional to automated milking on teat skin condition. J. Dairy Sci, 86: 1646-1652.

Sapkota, R., R. Dasgupta, A. Malik (2012). BabaFarid Institute of Technology, Dehradun, India, Department of Food science and Dairy technology, Baba Farid Institute of Technology, Dehradun, India Microbiological quality of potable water in Dehradun city.

Singelton, V. R., R. Orthifer, R. M. A. Lamuela-Raventos (1999). Analysis of total phenols and other oxidation substrates and antioxidants by means of Folin- Ciocalteu reagent. Methods in Enzymology, 299: 152-178.

Växa Sverige. Celltalsakuten. [online] (2015). Available from: http:/www.vxa.se/celltalsakuten. [Accessed 2015-02-20].

Vissers, M. M. M., F. Driehuis, T. Giffel (2007). Short communication:quantification of the transmission of microorganism to milk via dirt attached to the exterior of the teats. J. Dairy Sci, 90: 3579-3582. 